\title{
Masculinity, Matrimony and Generation: Reconfiguring Patriarchy in Drum 1951- 1983*
}

\author{
Lindsay Clowes
}

\begin{abstract}
In this article I discuss some of the ways in which Drum tended to ascribe 'modernity' to particular practices and processes in opposition to other practices and processes portrayed as 'traditional'. In mid-twentieth-century South Africa, dominant discourses tended to signal (white) male adulthood through independent decision making alongside financial autonomy. In contrast African discourses tended to signal male adulthood through proximity to family members, through respect for age and seniority and through deference to the praxis of 'tradition'. In the representations of black men in its pages, Drum magazine negotiated a somewhat disorderly path through these competing racialised discourses. I suggest that Drum's claim that black males were indeed men was made through highlighting and condoning practices that demonstrated similarities and continuities between subordinate black and dominant white versions of manhood. In challenging the racial discourse the magazine paradoxically found itself simultaneously reinforcing western rather than African versions of manhood.
\end{abstract}

[Dear Dolly] My father has already paid lobola for a girl I am not in love with, and keeps telling neighbours that she is my wife to be. I have a girlfriend of my own choice, and she is the one I want to marry and settle down with. Now should I marry the girl I have chosen, or marry the girl for whom lobola has been paid? I'm a modernized man, and I can't cope with the situation. The situation is leading me to cross swords with my old-timer who lacks understanding of my position. - S.T. Sibasa

A difficult problem indeed. It looks as though you will either have to defy your father, or marry a woman you don't love. But if you are a modernized man as you say you are, there is only one thing for you to do - marry the woman you love. ${ }^{i}$

As a present-day commentator has recently observed 'Drum dealt in a sober, wry, mocking, self mocking, angry, outraged and irrepressible way about the multifarious implications of being black in an African country run by Tarzan and Jane.'ii This paper explores some of these 'multifarious implications' through a consideration of the gendered meanings ascribed by Drum to some of the issues covered and questions asked (and answered) by the magazine between 1951 and when it was sold in 1984. I suggest that in its advice columns, investigative reporting and social commentary, the magazine repeatedly endorsed particular kinds of challenges to the patriarchal and generational structures of authority and seniority typically associated with rural areas. 
As argued elsewhere, the images and texts produced by the magazine tended to reinforce male authority over women, marginalize homosexual masculinities, and idealise particular constructions of domestic masculinity. iii The focus of this paper then is an exploration of some of the ways in which the magazine was inclined to privilege the gendered values emerging out of urban rather than rural contexts. More specifically - as highlighted by the extract from an advice column at the beginning of this paper - I explore how the magazine represented urban men's challenges to the values, aspirations and cultural practices typically associated with the structures of masculine authority built around age and seniority emerging out of more rural ways of life.

\section{Manufacturing Drum}

The first edition of The African Drum - a Magazine of Africa for Africa (subsequently to become simply Drum) appeared in March 1951. iv Initial sales, at sixpence a copy, were disappointing, but began to improve after a management shake-up in which control of the magazine shifted to Jim Bailey. After co-director Robin Stratford withdrew, Bailey swiftly replaced Bob Crisp, the immensely experienced original editor, with newly graduated Englishman Anthony Sampson who knew almost nothing of publishing and even less of South Africa. ${ }^{v}$ And from more or less the same time, a shift in strategy aimed at winning more readers saw increasing numbers of black male journalists and photographers being hired. Men like Henry Nxumalo, Todd Matshikiza, Arthur Maimane, Can Themba, Casey Motsisi, Ezekiel Mphahlele and Nat Nakasa, as well as Bob Gosani and Peter Magubane who were (or became) the leading black intellectuals of the day. The shake up and strategizing paid off and by the mid 1950s circulation had climbed to about 70,000 in South Africa with another 30,000 distributed outside South Africavi $^{\mathrm{vi}}$ And it seemed - at least to the makers of the magazine - that Drum had established itself as a firm feature of the publishing landscape. As Henry Nxumalo observed at the time:

From the coffee plantations of the Gold Coast to the jazz-stung night spots of Nigeria, from the slow pomp of Uganda's royal ceremonies to the livid frenzy of Kenya's turmoils; in the dreaming hamlets of Zululand; among Cape Town's fun-filled coon life and Johannesburg's teeming, thrilling thousands everywhere, every month, Drum is read and relished.vii

Two years later, in 1958, in an advertisement in a local marketing journal, Drum claimed a readership of 3,500,000 readers spread across South, Central, East and West Africa. viii Drum's owner, Jim Bailey, has stated that between 50 and 100 people looked at each copy sold. ${ }^{\text {ix }}$ While these sorts of claims are impossible to verify, other evidence supports the idea that Drum was widely accessible. Wole Soyinka notes that the 'average Nigerian reader' of the mid 1950s 'was weaned on Drum'x; it was the magazine 'particularly enjoyed by students' through subscriptions taken out by schools across the continent. ${ }^{\mathrm{xi}}$ Kenda Mutongi reports that Drum was to become 'one of the most popular magazines in Anglophone Africa in the 1960s and 1970s'. xii Even Julius Nyerere allegedly supported Drum on the grounds that the magazine helped 'spread literacy' through its pictures 'which attract people's eyes and minds [and] make people want to read'. xiii

Drum's popularity at home in South Africa is a little easier to establish. In 1958 Selling Age, a local marketing journal, independently estimated Drum's audience to be 
865,000.xiv Rising circulation tended to lend authenticity to the magazine's claims to represent the 'true' African voice. This claim was further validated by repeated clashes with the Nationalist government, which believed Drum and it's writers to be powerful shapers of public opinion. ${ }^{x v}$ State efforts to censor the press escalated from the middle of the 1950s, and in 1956, for instance, Sylvester Stein (Sampsons's replacement), Can Themba, Peter Magubane and Jurgen Schadeburg were all arrested.xvi By the early 1960s several of the magazine's writers had left the country rather than continue to have their voices stifled by the increasingly repressive regime and it was this, alongside financial difficulties and the arrest and detention of the Durban editor, that probably induced Bailey in 1965 to convert Drum into a supplement to Golden City Post.xvii Three years later, though, Drum was back and so successfully re-established itself in the market that Bailey decided to issue two copies a month from January 1972. The 1970s saw several editions banned and the magazine become embroiled in what was to become known as the 'Muldergate' scandal in which the Nationalist government made an unsuccessful attempt to secretly purchase the magazine. ${ }^{\text {xiii }}$ In the early 1980s more editions were banned until finally, in April 1984, the Rand Daily Mail revealed that Bailey had sold Drum to Nationale Pers, bastion of the Afrikaner press. ${ }^{\text {xix }}$

While most of those who purchased the magazine were men - at least in the early years - copies were handed round and shared amongst friends and family and there is little way of knowing the gender breakdown of the magazine's readership. ${ }^{\mathrm{xx}}$ But perhaps more telling than readership estimates is the way in which Drum, particularly in its earlier years, has become an icon of South African history. It is widely acknowledged in South Africa that the writers and photographers of Drum helped set up a tradition of independent black writing that has left an important historical and cultural legacy. This legacy is evident in the establishment of the Nat Nakasa Award for Courageous Black Journalism in 1998, followed by a documentary of Nakasa's life screened on prime time South Africa television the following year. Both short stories and opinion pieces first published in the magazine have found their way into collected editions. The magazine's photographers have won a variety of prestigious awards and exhibited their work in some of the world's major galleries. Newspaper stories reflecting on the significance of Drum still appear from time to time in South African newspapers. More recently, the year 2004 saw the completion (to mixed reviews) of a film called simply Drum that purports to tell the story of the magazine and its producers. The academy too, has identified Drum (and its writers) as significant: Dorothy Driver notes that Drum magazine is 'crucial in South African literary and cultural history'. xxi

\section{Representing subjectivities in Drum}

Popular magazines such as Drum are key elements of the popular media, and it is almost axiomatic now to argue that they exert a 'cultural leadership' that helps to shape consensus and ways of interpreting reality. ${ }^{x x i i}$ As Stuart Hall notes:

[T] he more one accepts that how people act will depend in part on how the situations in which they act are defined, and the less one can assume either a natural meaning to everything or a universal consensus on what things mean - then, the more important, socially and politically, becomes the process by means of which certain events get recurrently signified in particular ways. ${ }^{\text {xxiii }}$ 
All societies, states Connell, make use of gender regimes - that is, the patterning of relationships between, and within, groups of men and women. 'The overall patterning of gender regimes, together with the gender patterning of culture and personal life, may', he argues, 'be called the gender order of a society.' He goes on to add that 'implicit in these concepts' is the notion 'that gender regimes and gender orders are historical products and subject to change in history'.xxiv Informing an individual's deeds and thoughts, gender structures each individual's interpretation of reality in particular ways. Gender then, as Kimmel argues, 'is a central feature of social life' and 'one of the central organising principles around which our lives revolve'. $x x v$ But, as Patricia Hill Collins and others have warned, we need to take care not to elevate gender above other socially constructed aspects of our identities. ${ }^{x x v i}$ And as Mama, Abrahams, Gqola and Thornton Dill have all noted in different ways, it is precisely the intersections between gender, race, class, sexuality, ethnicity, age and so on that are so important.xxvii

In this article, then, I take the position that each individual experiences and makes sense of his or her world from a position located at the intersection of a multitude of competing, shifting, fragmentary, complementary and often contradictory identities alongside gender such as race, age, class, ethnicity, religion, age and sexuality. Thus masculinity for instance is understood 'not as a monolithic entity, but as an interplay of emotional and intellectual factors - an interplay that directly implicates women as well as men, and is mediated by other social factors, including race, sexuality, nationality, and class' ${ }^{\text {xxviii }}$ Like femininity, masculinity is conceived as a complex and multifaceted identity that is actively and creatively produced by men through the intersecting relationships with other identities such as those of sexuality, age, race, class and ethnicity in each particular historical and cultural context. In the sense that each man has to construct his own masculinity there are then, as Connell has claimed, multiple masculinities ${ }^{\mathrm{xxix}}$ in which each specific version, as Mac an Ghaill explains, 'can be seen as a crucial point of intersection of different forms of power, stratification, desire and subjective identity formation'.xxx Overall thus, I understand gender, sexuality, masculinity and femininity as socially and historically constructed identities that inform and shape each other as they are enacted in daily life, as they are themselves shaped by the dialectical relationships with the competing and complementary identities outlined above.

These complex subjectivities, constructions of particular social and historical landscapes, are inevitably reflected in the media products finally offered to consumers. Thus although readers themselves construct meaning through their engagement with the text, the range of available meanings is framed by the people who made the magazine as well as the ways in which both visual and verbal texts are structured by language and genre. And, of course, any reading takes place against a backdrop of specific social and historical contexts, as the work of Hofmeyer, Lubbe, Terreblanche and Wilbrahim suggests. ${ }^{x x i}$ As Ferber has noted 'reality itself is written within cultural systems', and in terms of relations of power and dominance what is at stake is which and whose 'narrative structure will prevail in the interpretation of events in the social world'.xxxii Defining rape as 'tough love' and rapists as 'tough Casanovas', as the male producers of Drum did in 1957, is just one particularly overt example of how the magazine was able to contribute to constructions of masculinity, femininity and gender that worked against women. ${ }^{x x x i i}$ Having said this, the interpretations of contemporaneous readers are largely beyond the scope of this paper, although insights 
can be gleaned from the letters and queries from readers that were published. Instead, my focus is on some of the ways in which such readers might have made sense of the magazine. The exposition above thus aims to provide an outline of my theoretical positioning with which contemporary readers can understand my reading of the magazine.

\section{Audience and context}

What has come to be known simply as Drum was born into a post-World War II society in which industrialisation and urbanisation had brought significant change in South Africa's racial and ethnic demography. Census records indicate that there were more than two million black South Africans living in urban areas in 1951, compared to just one million in 1936.xxiv Thus by 1951 the rural migrant labour workforce upon which white industrialists had previously relied had been supplemented by an urban black working class; a working class that was both 'settled' and 'permanent' according to a government commission of 1948. ${ }^{\mathrm{xxx}}$ It was, as suggested earlier, this ethnically mixed, urbanised and urbanising black population that was to become Drum's main audience in the early 1950s. xxxvi

With the social and material conditions of life in town so different to those of the rural areas new ways of demonstrating gender, ethnicity, class and other signifiers of social identity had to be found. Acceptable urban dress for instance, was very different to that which was the norm in rural areas, and western suits replaced cattle, wives and children as signifiers of status and wealth in towns where there was no space for large herds. .xxvii While, for example, urban individuals often preferred to live in close proximity to others of the same ethnic group, they were also exposed to individuals from different ethnic, cultural and religious traditions as well as the newer urban groupings of tsotsis and gangsters. ${ }^{\text {xxxviii }}$ In this new urban milieu the values and practices that had been taken for granted at 'home' were increasingly contested and individuals challenged to find new ways of establishing and signaling meaningful urban gendered identities. It was here - as a guide to urban living, as a medium by which everyday and newsworthy events were signified - that Drum played a role.

The urban landscape upon which this was played out as the second half of the twentieth century unfolded owed much to earlier equilibriums reached in rural areas around gender and generation. While not implying that gender relationships had ever been static, conquest and the construction of colonial and customary law had undermined the balances achieved through earlier negotiations. McKittrick observes that intergenerational conflict between men in Namibia was not created by colonialism but that such tensions and conflicts were enhanced by processes of '[p]olitical centralization, Christianity, migrant labor and colonial rule' which 'all allowed young men new scope to redefine prevailing notions of masculinity, reduced young men's dependence on fathers in some respects, and yet ultimately reinforced the dominance of an elite group of men over other men and all women'. xxxix

Economic, social and political change thus contributed to shifts in the precarious and tension filled checks and balances of rural authority in complex ways. As Mann and Roberts note, while the construction of customary law had tended to privilege senior black men and entrench the subordinate status of black women and junior men, it had 
also simultaneously offered new opportunities for subordinate men and women to challenge patriarchal authority. ${ }^{\mathrm{xl}}$ In southern Africa, the discovery of gold and diamonds and the rapid expansion of the mining industry opened up further opportunities to young men that allowed them to move away from the influence and authority of older men in the countryside and which subsequently saw the deepening of tensions around generational authority centred on issues of bridewealth, marriage and inheritance. As McKittrick observes, the 'closing years of Ovambo autonomy' saw, '[m]issions and migrant labor promise a measure of independence from local male power brokers, although they inevitably ensnared men in new relations of dependence'. xli Likewise, shifting patterns of agricultural production in Natal, for example, 'left crucial openings for subalterns that threatened to undermine the authority of African farmers and white settler farmers'. xlii In the context of economic hardship, migrancy, urbanisation, the spread of Christianity, consumerism and the money economy alongside the decay in traditional patterns of authority, increasingly marginalised rural patriarchs had even joined forces with white men in an effort to reassert male controls over rural women. ${ }^{\text {xliii }}$

However, although colonialism, industrialisation, migrancy and urbanisation might have undermined the material basis of rural economies, the history of these societies remained, as Morrell notes, 'woven into a myriad of gendered rituals which served to legitimate the sexual division of labour and male power. In the South African countryside, older men commanded respect. They were part of a gender system which had, at its apex, the chief. xliv Several studies undertaken in the middle of the twentieth century support such a conclusion. Gelfland observes that in Shona society 'a child is taught to consider others, especially elders and seniors' and that even for grown up children '[p]arents and elders, especially parents, were considered as the head of the

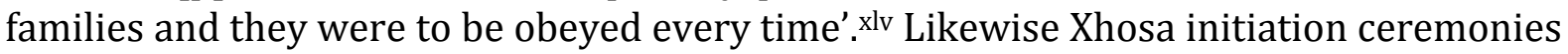
emphasised that an initiate should '[l]ook after your parents and obey them, remembering that to them you are not a man and will remain a boy'. ${ }^{\prime l v i}$

Parents -- particularly fathers as well as other senior male kin -- were important in decisions about marriage partners too. Prospective wives and husbands were selected by parents rather than young people themselves, with the marriage representing the joining together of families and clans rather than indulging the romantic affections of individuals. For McClendon marriage was 'the principle site of gender and generational dynamics'. xlvii But while acquiring a wife and then a son might bring full adulthood to a young man, even after his marriage the '[r]ed Xhosa man is [still] expected to regard himself as definitely 'under' his parents. xlviii For the newly married woman the emphasis was on her duties as a daughter-in-law rather than as a wife and she 'works for and owes obedience to her husband's parents or senior kin', statements further demonstrating the gendered connections between families and generations that marriage served to produce. .lix $^{2}$

The culture of obedience and subordination to one's parents and senior men had, especially in urban areas, had by the end of the nineteenth century begun to break down. Carton alludes to early twentieth century complaints from rural patriarchs about the 'blatant youthful defiance' of returning migrants. ' While McClendon suggests that 'conflict between rural fathers and sons is inevitable where marriage is predicated on bridewealth', he also goes on to observe that 'relations between fathers and sons were deeply affected by the colonial situation' and that the twin processes of urbanization 
and industrialisation were feeding this conflict. 'The increase in wage labor and in urban jobs gave sons geographic independence and independent access to bridewealth. The deteriorating conditions in the countryside, particularly the farms also meant that young men were less able to rely on their fathers for the accumulation of bridewealth and this further encouraged them to spend longer periods in the cities or to relocate permanently'.li

The 'blatant youthful defiance' on the part of young men was made possible by the wage economy based in the towns and mines which upset traditional arrangements whereby in rural areas 'all effective control of this world's goods was vested in the senior males'. lii But while younger men acquired increased access to the economic resources that allowed them to marry, for instance, their challenge to the system tended to end after their marriage when, in the rural areas at least, they in turn had a vested interest in maintaining the structures of seniority based on age, marital status, cattle and so on. Yet, by the middle of the twentieth century, the urban 'juvenile delinquency problem' was widely recognized. Numerous authors have pointed to the generational conflicts between men that had come to characterise urban life in the mid-twentieth century. liii Their claims are reinforced by even a superficial examination of Drum, where complaints about Tsotis, gangsters and insubordinate young men abound.

\section{Drum, masculinity and generational authority}

For those young men who found themselves in South African towns in the middle of the twentieth century, challenges to the authority of older men were material, in terms of their access to cash and the status symbols money could buy, as well as ideological. Overall, although often with considerable ambiguity, Drum tended to take the side of the young and the urban against the rural and the old. Fenwick has noted, for example, the ways in which the magazine consistently admonished 'young people not to get involved in crime' while simultaneously highlighting 'the excitement and adventure of the gangster-figure's expensive urban lifestyle and the protection afforded by gangmembership.'liv 'Far from being hooligans and ruffians', stated one columnist, tsotsis 'are the sophisticated young men of the new age.'v At the same time, men whose occupations could not easily be accommodated into the urban western future found themselves at the receiving end of Drum's implicit and explicit social critique. Rural (and even urban) men with high social status, such as Sangomas, were described as witchdoctors (an offensive term) and ridiculed in the pages of the magazine.

Asking the question 'Should Witchdoctors be Banned?' an article published in September 1954 alerted readers to the notion that the traditional custodians of African cosmology perhaps belonged in the rural past rather than the urban present and future. The magazine published letters about Sangomas and traditional healing that were extremely offensive, and that would almost certainly have ended up in court for slander and libel had journalists uttered them against specific individuals. 'It is a racket that often gives patients poisonous roots, and by the time they are taken to hospital it is too late' argued John Tatane, himself a medical doctor. He was backed up by another male reader who declared that ' $[\mathrm{w}]$ itchdoctors practise a mysterious and suspicious cult. They have been responsible for gruesome ritual murders!'lvi Two years later, a challenge to all 'witchdoctors' served to further distance the men of the magazine from these nonwestern practices. Pointing to the gullibility of people who believed claims that 
witchdoctors could 'wither away and burn to ash a man's arm', Drum declared that 'we don't believe it can be done. We don't believe it at all and we throw out a challenge to all witchdoctors to wither away Mr. Drum's [Henry Nxumalo] right arm.' And, putting its money alongside its mouth, the magazine promised that ' $[t]$ he first person to do it wins $£ 1,000$ '. lvii While Nxumalo's mysterious murder less than six months later might have seemed like retribution to some of those who had been so rudely challenged, any possible connection was not commented upon in the pages of the magazine. By contrast, western style medical doctors and even Christian-based 'faith healers' received a much more positive press. .viii $^{\text {lii }}$

Questioning, as Drum did in the mid 1950s, whether 'tribal customs and culture [should] be kept', effectively questioned the authority of those religious and cultural leaders (more often than not senior men in rural areas) who, firstly, upheld such customs and, secondly, owed their social and political status to such customs. Respected urban-based individuals such as Mopeli Paulus went on the record in the magazine to support the jettisoning of 'tribal customs'. 'We live', he argued, 'in a Westernised world and Western civilisation has a history and tradition of over 2000 years. African customs and culture have no set standards. What is there to keep of them anyway?'lix Almost 50 per cent of the respondents agreed with him, and Drum's publication of extracts from their letters both widely disseminated and leant additional weight to such challenges to 'customs and culture'.lx And lest there be any doubt '[l]et's admit it', the magazine declared a few years later, 'things have changed so much since our tribal days that there is no point clinging to the outmoded ways of yesterday.'Ixi

Drum tended to take sides with the young and urban when reporting on the challenges and tensions around the social status of older men and the patterns of respect for seniority upon which African social structures had long been built. Although the first edition of the magazine had seen Mr Masangu 'a sturdy old African peasant' selected as the figure of authority to introduce the publication to South African audiences, later editions tended to disparage those who had reached old age without making their mark

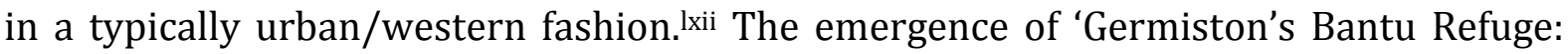
the house of the forgotten people', for example, where 'hundreds of aged Africans wait to die', was blamed primarily on the old themselves rather than on the social, economic and political changes taking place in a racist capitalist society. 'Imbeciles, epileptics, and perverts bask in the sun, eat, sleep and wait... wait for the blessing of death. They have been forgotten by their relatives and friends', reported the magazinelxii. Although the magazine did acknowledge that some of the men (not women) had 'respectable' working pasts, it did not, in this instance, problematise the social, economic and political changes that gave rise to the need for such a refuge. In many ways the magazine quietly endorsed such changes: when one young woman complained that her future husband would not permit her aged parents to live with them, Drum supported his position rather than hers. ${ }^{\text {xiv }}$

Already crumbling traditions around marriage and the gendered linkages it embodied between generations and between families were further challenged by Drum's dismissal of lobola as well as its somewhat ambiguous approach to polygyny. Lobola, the magazine suggested on very little evidence, was perceived as an 'outdated' tradition by many young people, an 'old fashioned' practice that had no place in modern society. $\mathrm{xv}$ More complicated was the magazine's response to polygyny. In the past those (usually 
older) men with high social status (and the cattle to prove it), had been able to demonstrate their position in the world by taking a second or even a third wife. But by the mid 1960s, '[p] olygyny [was] of negligible incidence in Soweto'. Instead it was being replaced 'by a system of concubinage and extra marital liaisons' in which youth and access to cash played at least as important a role as age and cattle. ${ }^{\text {lxvi }}$ Drum did not appear to approve. 'No decent man would fall in love with two friends' stated Dolly in the heartbreaks column. ${ }^{\text {xvii }}$ When another man - trying to do the right thing - asked how to get his mistress and the mother of his only child to live with his barren wife of 14 years because he loved both women he was chastised for being 'silly' and told he 'should be ashamed of [himself].... you cannot have two wives'. lxviii A man who had three children with one woman, and who had paid half lobola for her was written off as a 'dirty trickster', and as 'being very silly indeed' when, in line with traditional practices and the demands of his family, he took on his dead brother's wife and asked the mother of his children to become his second wife. lxix

There are, on the other hand, numerous ways in which the magazine played into the double standards of western sexualities. As Fenwick notes the endless articles about gangs were couched in language that somehow simultaneously expressed envy and disapproval of the multiple sexual liaisons that gang leaders (who were generally

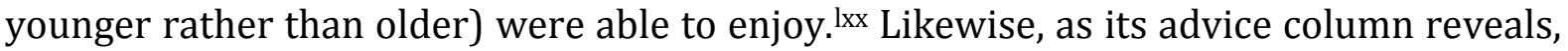
the magazine's disapproval of multiple sexual partners was infused with ambiguity. While Drum consistently espoused monogamous heterosexual marriages, and single partner relationships, the asymmetrical heterosexism of the west seemed to have meshed relatively easily with traditional rural constructions of sexuality and masculinity in which men - but not women - were permitted multiple sexual partners. Although husbands, for instance, were advised not to have affairs, it was wives who were instructed, at least early on, to forgive and forget when their husbands strayed. While single men who claimed to have more than one partner were ridiculed in the advice columns, and single women were often advised to dump men who saw other women, women (but seldom men) were also often advised to give these men a chance, to wait and see if their behaviour improved. 'You will either have to accept his needs or accept his other girlfriends.... You could take the attitude that life is a gamble and you might as well give him a chance.'Ixxi

In terms of finding marriage partners, the advice column represented one of the key ways through which Drum privileged the aspirations of the young rather than those of their parents and elders. Driver has noted that the magazine:

blandly reproduced European and American constructions of gender as part of an overall ideology of romantic love. This was not romantic love in the courtly tradition, but a modern form of romantic love within an ideology of domesticity, aiming for the establishment of a consumer oriented nuclear family, headed by the husband and father and hospitable to female authority in only its most carefully controlled domestic forms. ${ }^{\text {lxxii }}$

One aspect of this notion of 'romantic love' is the way in which western notions of romance have been built around individual choice. In the west (in the recent past at least), companionate marriage has been constructed as a formal arrangement undertaken between two individuals for love. And this was the version disseminated by 
Drum. Despite long traditions of marriage as a gendered institution arranged by, and connecting, families across generations it was marriage between youthful individuals from the same generation that Drum endorsed on the grounds that love was 'the most important thing when two people think of getting married'. Ixxii 'Love' Drum declared ahistorically, and illustrating the concept by portraying a young couple on the cover, 'is a story of youth all over the world; East, West, North and South'. Lauding individual choice as natural, right and inevitable, the article supported the demands of those who wished to choose their own partners rather than have parents or other senior relatives 'force' (as the magazine put it) a selection upon them. lxxiv 'True love', as the magazine insisted a few years later, 'knows no barriers'.

Obliterating the historical legacy of cultural, religious, ethnic or any other social factors, along with familial and parental participation in the conjoining of couples, Drum made its position apparent: it was a young man's prerogative to choose a wife. 'I]f [your mother's] reasons are not good enough and you are sure that this girl will make you happy, by all means marry her'. lxxvi Once 'you're over 21 [you] no longer need your parents' consent to marry. But, for courtesy's sake ... have another talk with them'.lxxvii 'Nothing can stop you from getting married if you are both over 21', reiterated the magazine over and over again. lxxviii And as the years passed such advice became ever more forthright. When one reader argued that '[i]n these modern times the choice in marriage should be left entirely to the boy and girl concerned', and that it was 'high time parents realized the importance of this', Drum was in wholehearted agreement that the correspondent had 'just knocked another nail into the coffin of a dying tradition'. Readers asking for advice about marriage partners were repeatedly instructed to ignore their parents: '[a]s for your parents' choice - forget her, my friend!lxxx 'If your parents insist on not seeing reason, then you can go ahead and marry your man. You're both of age and can do so without their consent'. 'xxxi Thus instead of attributing supreme value to the words and advice of their fathers and mothers, Drum consistently encouraged young men (and women for that matter) to defy their traditions as well as their 'unreasonable' and 'inhumane' parents. ${ }^{\text {lxxxii }}$

Over the course of the 1970 s and early 1980s there were shifts in the events and processes deemed newsworthy by the men who made the magazine. There were far fewer references to 'witchdoctors', polygyny and other 'outdated' customs and practices; towards the 1980s articles in which men's physical health seemed to have become women's responsibility began to appear. lxxxiii Another sign of change was the increasing numbers of reports about women taking on traditionally male roles. In November 1970, for instance, Drum reported on female teachers, entertainers, lawyers and medical doctors in a report entitled 'gatecrashers among the men'. lxxxiv Just three years later the magazine was featuring the first four black women to be made 'life vicepresidents' of the South African federation of professional women. ${ }^{\operatorname{xxxv}}$ But there were continuities too. In 1976 the magazine reintroduced its 'Masterpiece in Bronze' column in which it paid tribute to local entertainers, politicians, businessmen, sports stars and so on - men (very seldom women) who had made their mark on the modern world. lxxxvi There remained, in addition, countless letters from readers asking for advice about how to manage their parents, and Drum continued to advise young people not to 'allow your mother to thwart your future happiness'lxxxvii; 'you must tell your parents not to interfere'lxxxviii; 'it is up to you to choose your wife. Don't allow your parents to make up your mind for you'.lxxxix 
Perhaps the most interesting change over the course of the 1970s was the increasing focus on the 'illegitimacy' of the laws surrounding interracial heterosexual relationships. White men's liaisons with black women had been an open secret in the urban townships but stories about such interactions had seldom made the pages of the magazine before the 1970s. The magazine had endeavoured to draw attention to the futility of 'legislating against nature' back in 1957, and had at the same time exposed a brothel in Cape Town where black men paid $£ 5$ for intercourse with white women. ${ }^{x c}$ During the 1970s and early 1980s Drum devoted a great deal of space to these kinds of illicit liaisons, pointing over and over again to the relationships between white men and black women, and just once to the relationship between white woman Regina Brooks and a black man. ${ }^{x c i}$ In the racialised context of apartheid the sub text was that 'men' were clearly those who were able to choose their heterosexual partners from the full range of women, and the immorality laws were hypocritical in ostensibly limiting white men's choices. ${ }^{x c i i}$ Not only were such laws hypocritical, argued Drum, they were also damaging to white men as a report identifying nineteen white men all allegedly dead as a consequence of the Immorality Act of 1957 made quite clear. xciii 'Sexuality', states Ferber, 'becomes the performance of one's gender', and apartheid was an inherently gendered project.xciv

In its attempts to construct and maintain a hegemonic heterosexual white masculinity that was validated through laying public claim to women and women's bodies, apartheid necessarily involved the public denial of certain women's bodies to other men. This, I suggest, was the crux of the matter for Drum, and it was black men's sexual access to white women that represented another piece of the claim that black males were also men.

It is self-evident that Drum cannot be held responsible for the decay of the traditional, rural, patriarchal and gerontocratic order that had been crumbling as a result of conquest, Christianity, migrancy, racist urbanization and industrialisation, consumerism and the monetisation of lobola since the middle of the twentieth century. By 1951, when the magazine was first published, earlier structures of power and systems of authority built around age, seniority, and gender had already been seriously destabilized. As Barnes has observed in colonial Harare, the 'reconsolidation' of systems of gendered, racialised, [and sexualized] patriarchal power were expressed through complex conflicts and tensions in the rapidly growing urban areas. ${ }^{x c v}$ It was through ascribing meaning to change - and providing 'scripted' responses to change - that Drum helped contribute to the production of new urban identities in which race, gender, sexuality and age continued, in different ways, to matter enormously. In the urban black townships power and authority were increasingly more likely to be vested in younger men and/or men with money.

At the same time, the construction of these new urban identities and power relationships took place in a context of an increasingly intolerant and progressively more inflexible white supremacism that attempted to deny manhood to black men. While some have suggested that the black writers of Drum helped sustain racist images by absorbing 'into their consciousness the white stereotype of the black savage'xcvi, others have challenged such assessments suggesting instead that the magazine helped black South Africans 'begin to realize their own intrinsic importance as human beings' 
by helping to 'destroy the sense of inferiority and futility which has eaten into the very vitals of our national life, generation after generation.'xcvii Certainly there is little question that the overarching framework of the very particular white hetero-patriarchal racism that constituted apartheid infused the magazine's representations of black men and their versions of masculinity. As noted earlier, several writers have pointed to the generational conflicts between black men that had emerged out of the complex economic, social and political changes that had come to characterise urban life by the middle of the twentieth century. These intergenerational conflicts were an important element of the tensions and challenges embedded in constructing a hegemonic urban masculinity in the rapidly growing towns and cities of mid-twentieth-century South Africa. Drawing on western gender discourses that privileged particular kinds of men and particular kinds of male authority, Drum tended to authenticate the position of those who claimed certain 'modern' (that is, western) values, its pages portraying a dominant urban masculinity in which the authority of age and tradition was diminished.

The magazine's privileged place within urban black communities thus helped affirm and endorse an urban gender regime in which young men - and to a much more limited extent young women - found an important ally in certain of their challenges to their families and their fathers. In their disorderly attempts to represent black manhood in a context in which white racist discourse constructed black men as boys, the producers of Drum had little choice but to partially accept dominant discourses around masculinity. Challenges to these discourses that emphasized a masculinity built around subordination to parental and /or 'traditional' authority ran the risk of reinforcing the racist notion that black men were not men. If it was the ability to make independent decisions about marriage partners that signaled adulthood - as it did in the west - then a male who listened to his elders and who had a partner selected for him risked being seen - by the white authorities - as more of a boy than a man. Bearing this in mind then, the changing images of black men presented in Drum are better understood as the consequence of a process by which black writers elected to adopt and adapt from the overarching hegemonic framework of western hetero-patriarchal racism in ways that reclaimed authority and agency.

\section{Conclusion}

This article considers some of the meanings produced by Drum magazine since the first edition in March 1951 up until the magazine was sold in 1984. I discuss how Drum tended to ascribe 'modernity' to particular practices and processes in opposition to other practices and processes that were portrayed as 'traditional'. In mid-twentiethcentury South Africa dominant discourses tended to signal (white) male adulthood through independent decision making alongside financial autonomy. In contrast African discourses tended to signal male adulthood through proximity to family members, through respect for age and seniority and through deference to the praxis of 'tradition'. For newly urbanized and urbanizing black South Africans, routes through these competing, unevenly weighted and differentially valued discourses had to be carefully negotiated, and challenges to dominant discourses around race and gender ran the risk of reinforcing racist ideas that black men were not men. Thus in town, signaling male adulthood through obedience to one's seniors and through subscribing to the traditions of one's forebears ran the risk of establishing adult black men as immature males. In the representations of black men in its pages, Drum magazine negotiated a somewhat 
disorderly path through these competing racialised and gendered discourses. I suggest that Drum's claim that black males were indeed men and not boys was made through highlighting and condoning practices that demonstrated similarities and continuities between subordinate black and dominant white versions of manhood. In challenging the racial discourses around masculinity the magazine paradoxically found itself simultaneously reinforcing western rather than African versions of manhood.

\author{
Lindsay Clowes \\ Women's \& Gender Studies Programme \\ University of the Western Cape \\ Private Bag X17 \\ Bellville \\ 7535 \\ South Africa \\ Lclowes@uwc.ac.za \\ clowesL@mweb.co.za
}

\footnotetext{
*I would like to thank the anonymous reviewers of the Journal of Southern African Studies for their helpful comments.

i Drum, 22 December 1975, p. 28.

ii J. Matshikiza, Mail \& Guardian, 20-27 April 2000, p. 6.

iii D. Driver, 'Drum Magazine (1951-1959) and the Spatial Configuration of Gender' in K. Darian-Smith, L. Gunner and S. Nuttall (eds). Text, Theory, Space: Land, Literature and History in South Africa and Australia (London: Routledge 1996); L. Clowes, 'Historical Representations of Race, Masculinity and Homosexuality' in K. Ratele and N. Duncan (eds.), Social Pyschology: Identities and Relationships (Cape Town: University of Cape Town Press 2003); L. Clowes, 'Men and Children: Changing Constructions of Fatherhood in Drum Magazine1951-1960' in L. Richter and R. Morrell (eds.), Baba? Men and
} Fatherhood in South Africa (Pretoria: Human Sciences Research Council, 2006).

iv The African Drum, March 1951, cover page.

$\checkmark$ A. Sampson, Drum: A venture into the new Africa (London: Collins 1956) p. 14.

vi The magazine was set up by Jim Bailey, Robin Stratford and Bob Crisp. Bob Crisp, the initial editor was replaced by Anthony Sampson in late 1951. A. Sampson, Drum, p.198.

vii Henry Nxumalo 1956, cited in the Cape Times: Top of the Times, 15 October 1999.

viii Selling Age, May 1958, p. 8.

ix Jim Bailey interviewed on SAFM, 25 October 1999.

x W. Soyinka, Art, Dialogue and Outrage (Ibadan: New Horn Press 1988), p.168.

xi P. Nazareth, An African View of Literature (Evanston: North Western University Press, 1974), pp.189, 221.

xii K. Mutongi, 'Dear Dolly's Advice: Representations of Youth, Courtship and Sexualities in Africa, 1960-1980', International Journal of African Historical Studies, 33, 1 (2000), p. 1. [pp.1-23]

xiii J. Nyerere in T. Hopkinson, In the Fiery Continent (London: Victor Gollanz, 1962), p. 221.

xiv Selling Age, November 1958, p. 17.

xv For example the Prisons Act of 1959 which made it risky to publish information about prisons and their inhabitants also 'rendered it an offence... to sketch or photograph a prison... a prisoner, or the burial of an executed prisoner' and was partly in response to a story in Drum according to Muriel Horrell. M. Horrell (ed.), Laws Affecting Race Relations in South Africa, 1948-1976 (Johannesburg: South African Institute of Race Relations, 1978) p. 411; E. Potter, The Press as Opposition: The political role of South African Newspapers (London: Chatto \& Windus, 1975), p. 123.

xvi C. Merrett, A Culture of Censorship: Secrecy and Intellectual Repression in South Africa (Cape Town: David Philip, 1994), pp. $29,38$.

xvii L Clowes 'A modernised man' Changing constructions of masculinity in Drum magazine, 1951-1984' Unpublished Ph.D thesis, University of Cape Town, 2002.

xviii Ibid.

xix lbid.

$x x$ 'The typical reader', states Sampson, were 'urban men...because they had the spare cash'. Anthony Sampson interviewed in London by the author, 18 $18^{\text {th }}$ July 2000 . Sampson's claim is supported by research conducted by a local 
advertising journal which showed that 40 percent of the sales between May 1956 and August 1956 occurred in the Witwatersrand/Pretoria regions (South African Sales Promotion and Packaging, November 1956, p. 38.)

xxi D. Driver, 'Drum Magazine', p. 231.

xxii E. McCracken, Decoding Women's Magazines: From Mademoiselle to Ms (New Hampshire: Macmillan, 1993) p. 3.

xxiii S. Hall, 'The Rediscovery of 'Ideology': Return of the Repressed in Media Studies' in O. Boyd Barret and C. Newbold (eds.), Approaches to the Media (London: Arnold 1997), p.356.

xxiv R. Connell, The Men and the Boys (Cambridge: Polity and Blackwell, 2000), p. 29.

xxv M. Kimmel and M. Messner, Mens' Lives (New York: Macmillan 1992), p. 2.

xxvi P. Hill Collins, 'Moving Beyond Gender: Intersectionality and Scientific Knowledge' in M. Marx Ferree, J. Lorber and B.B. Hess (eds.), Revisioning Gender (Thousand Oaks: Sage 1998).

xxvii A. Mama, Beyond The Masks. Race, Gender and Subjectivity (London, Routledge 1995); Y. Abrahams, 'Learning By Doing. Notes Towards the Practice of Womanist Principles in the 'New' South Africa', Agenda, 50 (2001) pp. 71-76; P. Gqola, 'Ufanele Uqavile: Blackwomen, Feminisms and Postcoloniality in Africa, Agenda, 50 (2001) pp. 11-22; B. Thornton Dill, 'Women's Studies, Gender and 'Intersectionality', unpublished paper presented at the International Institute for Women's Studies, University of Maryland, (2001).

xxviii M. Berger, B. Wallis and S. Watson, Constructing Masculinity (New York: Routledge ,1995), p. 3.

xxix R. Connell, Masculinities (Berkeley: University of California Press, 1995).

xxx M. Mac an Ghaill, Understanding Masculinities (Buckingham: Open University Press, 1996), p. 4.

xxxi I. Hofmeyer, 'Building a Nation from Word: Afrikaans Language, Literature and Ethnic Identity, 1902-1924' in S. Marks and S. Trapido (eds.), The Politics of Race, Class and Nationalism in Twentieth Century South Africa (London: Longman, 1981); H. Lubbe, 'The Myth of the 'Black Peril': Die Burger and the 1929 Election', South African Historical Journal, 37, (1997) pp.107-132; H. Terreblanche, 'Mothers of the Nation: Afrikaans Women's Magazine Advertisements in the 1940s', Kleio, 28, (1996) pp. 174-188; L. Wilbrahim, 'Avoiding the Ultimate Break-Up After Infidelity: the Marketisation of Counselling and Relationship Work for Women in a South African Advice Column', Psychology in Society, 21 (1996); L. Wilbrahim, 'Few of Us Are Potential Miss South Africa's: an Analysis of psychological Discourses about 'Attractiveness' of Women's Bodies in Advice Columns, South African Journal of Psychology, 26, 3, (1996) pp.162-172; L. Wilbrahim, 'Dear Dr Delve-In: A Feminist Analysis of a Sex Advice Column for Women', Agenda, 30, (1996).

xxxii A. Ferber, White Man Falling: Race, Gender and White Supremacy (Lanham: Rowman \& Littlefield, 1999), p.7.

xxxiii Drum, June 1957, p.20, 22.

xxxiv Department of Statistics, South African Statistics 1980 (Pretoria: Government Printer nd), pp.1.17,1.13.

xxxv A Digest of the Fagan Report (Johannesburg: South African Institute of Race Relations nd.), p.7. (Fagan nd: 7).

xxxvi L. Clowes, "A Modernised Man?': Changing Constructions of Masculinity in Drum Magazine, 1951-1984', unpublished PhD, Department of Historical Studies, University of Cape Town, 2002.

xxxvii B. Carton, 'Locusts Fall From The Sky: Manhood and Migrancy in KwaZulu' in R. Morrell (ed.) Changing Men in Southern Africa (Pietermaritzburg: University of Natal Press 2002); M. Mckittrick, 'Forsaking their fathers? Colonialism, Christianity, and coming of age in Ovamboland, Northern Namibia' in L. Lindsay \& S. Miescher (eds.), Men and masculinities in Modern Africa, (Portsmouth: Heinemann 2003) p. 42; L. Clowes, "Are You Going to Be Miss (or MR) Africa?' Contesting Masculinity in Drum Magazine, 1951-1953', Gender and History, 13, 1 (2001) pp. 1-20.

xxxviii C. Glaser, Bo-Tsotsi: The Youth Gangs of Soweto, 1935-1976 (Portsmouth Heinemann, 2000); G. Kynoch, "A Man Amongst Men': Gender, Identity and Power in South Africa's Marashea Gangs', Gender and History, 13, 2 (2001) pp.249273.

xxxix McKittrick suggests that intergenerational conflict between men in Namibia was enhanced rather than created by Colonialism. M. McKittrick 'Forsaking their fathers?', p. 34.

xI K. Mann and R. Roberts, Law in Colonial Africa (Portsmouth: Heinemann 1991); C. Walker, Women and Resistance in Southern Africa (London: Onyx Press 1982); P. Bonner, "Desirable or Undesirable Basotho Women?': Liquor, Prostitution and the Migration of Basotho Women to the Rand' in C. Walker (ed.). Women and Gender in Southern Africa to 1945 (Cape Town: David Philip 1990).

xii M. McKittrick 'Forsaking their fathers?' p. 39.

xlii T. McClendon, Genders and generations apart: Labor tenants and customary law in segregation-era South Africa, 1920s1940s (Portsmouth: Heinemann, 2002) p. 1. According to Epprecht these kinds of changes also worked towards shaping and limiting the prospects of rural boys in colonial Zimbabwe from establishing themselves as full men. 'By the 1920s, it took many years of 'boyhood' for a biological man to earn the wherewithal to become a social man (that is, pay lobola, acquire a submissive and fertile wife, get land and support a growing family)', while 'the chances of acquiring... any of these... declined over time'. M. Epprecht, 'The Unsaying of Indigenous Homsexualities in Zimbabwe: Mapping a Blindspot in an African Masculinity', Journal of Southern African Studies 24, 4 (1998) p. 641 [pp.631-651]. In Mager's view, a response to similar difficulties facing mid twentieth century rural youths in the Eastern Cape had led some young men to express their manhood through the subordination of women. '[T]o be masculine was to assert male control over females in violent ways, to extract feminine obedience literally through the wielding of sticks'. A. Mager, 'Youth Organisations and the Construction of 
Masculine Identities in the Ciskei and Transkei, 1945-1960', Journal of Southern African Studies 24, 4 (1998), p.663 [pp.653-667.

xiii P. Mayer and I. Mayer, Townsmen and Tribesmen: Conservatism and the Process of Urbanisation in a South African City (Cape Town: Oxford University Press, 1974); B. Bozzoli with M. Nkotsoe, Women of Phokeng: Consciousness, Life Strategy and Migrancy in South Africa, 1900-1983 (Johannesburg, 1991); P. Bonner, 'African Urbansation on the Rand Between the 1930s and the 1960s: its Social Character and Political Consequences', Journal of Southern African Studies 21, 1 (1995) pp.115-130.

xliv R. Morrell, Changing Men in Southern Africa (Pietermaritzburg: University of Natal Press , 2001), p.13.

xiv M. Gelfland, Growing Up in Shona Society: From Birth to Marriage (Gweru: Mambo Press, 1985), pp. 220,48.

xvi M. Wilson and A. Mafeje, Langa: A Study of Social Groups in an African Township (Cape Town: Oxford University Press ,1973), p.107.

xivi T. McClendon, Genders and generations p. 17

xviii P. Mayer \& I. Mayer, Townsmen and Tribesmen, p.97.

xix Ibid, p. 98.

'B. Carton, 'Locusts' p.133.

li T. McClendon, Genders and Generations, p. 10.

lii P. Mayer \& I. Mayer, Townsmen and Tribesmen, p. 93.

liii K. Breckenridge, 'The Allure of Violence: Men, Race and Masculinity on the South African Goldmines, 1900-1950', Journal of Southern African Studies, 24, 4 (1998) pp.669-693; T. Barnes, We Women Worked So hard: Gender, Urbanisation and Social Reproduction in Colonial Harare, Zimbabwe, 1930-1956 (Portsmouth: Heinemann 1999); T. Dunbar Moodie with V. Ndatshe, Going For Gold: Men, Mines and Migration (Berkeley: University of California Press 1994); A. Mager, 'Youth Organisations'; B. Carton, 'Locusts', P. Mayer \& I. Mayer, Townsmen and Tribesmen; B. Bozzoli with M. Nkotsoe, Women of Phokeng; G. Kynoch, 'A Man Amongst Men; C. Glaser, Bo-Tsotsi; M. Fenwick, 'Tough Guy, eh?': The gangster figure in Drum', Journal of Southern African Studies, 22, 1996 pp.617-633.

liv M. Fenwick, "Tough Guy, eh?', p. 620. See also L. Clowes "Do you want to be Miss or (Mr) Africa?'.

Iv Drum, January 1958, p.11.

Ivi Drum, September 1954, p.15.

Ivii Drum, August 1956, p. 45. See also Drum, March 1959, p. $28 f f$ for a scathing critique of the use of Sangomas in local soccer. 'It is time to kick out the jujumen!.... 'Come to me' wheezes the witchdoctor, 'and l'll give you the magic that counts'.... The result is a big win - for the witchdoctor, one of the big enemies of sport today.... A long, long step backwards'. Also Drum, April 1963, p. 37 ff; December 1963, p. 53 ff

viii Drum, November 1959, pp. $22 f f$.

lix Drum, January 1954, p. 19.

Ix Drum, March, 1954, p. 33.

Ixi Drum, January 1958, p. 11

Ixi Drum, March 1951, p. 2.

xiii Drum, January 1956, p. 31.

Ixiv Drum, February 1953, p. 45.

lxv Drum, February 1959, p. 69; December 1961, p. 82.

Ixvi E. Hellman, Soweto: Johannesburg's African City (Johannesburg: South African Institute of Race Relations ,1971), p. 10.

Ixvii Drum, March 1954, p. 39.

Ixviii Drum, August 1954, p. 37.

xix Drum, December 1964, p. 65.

Ixx M. Fenwick, "Tough Guy, eh?'

Ixxi Drum, 8 October 8 1973, p. 35. see also Drum, July 1953, pp. 27, 43; October 1953, p. 25; January 1954, p. 39; May 1954, p. 45; June 1954, p. 43; November 1958, p. 11; December 1964, p. 64.

Ixxii D. Driver, 'Drum Magazine', p. 233.

Ixxiii Drum, March 1953, p. 45.

Ixxiv Drum, November 1955, p. 40

Ixxv Drum, June 1962, p.?

Ixxi Drum, October 1952, p. 43.

Ixxvii Drum, May 1953, p, 27.

Ixxviii Drum, August 1954, p. 37.

Ixxix Drum, June 1958, p. 11.

Ixx Drum, January 1959, p. 59.

Ixxxi Drum, April 1961, p. 73. For more examples see Drum,October 1959, p. 67; August 1961, p. 79; October 1961, p. 109; December 1961, p. 81; July 1962, p. 85; September 1962, p. 101; October 1962, p. 91.

Ixxxi Drum, May 1961, p. 81 
Ixxxiii For examples of exceptions to this trend see an article dismissing 'witchcraft' as 'rubbish' in Drum, March 1977, p. $14 \mathrm{ff}$, and a letter claiming that 'tribal' chiefs who pursued traditional practices were still living in the dark ages in Drum, April 1979, p. 14. An article giving wives views on polygyny appears in Drum, 8 October 1974 , p. 6, and another on the problems of King Goodwell Zwalithini's (sic)multiple marriages in Drum 8 July 1975, p. 5 ff.

Ixxxiv Drum, November 1970, p. 47 ff. See also Drum, 8 March 1973 p. 9; 8 September 1973, p. 39; 8 September 1975, p. 10 ff; June 1978, p. 42 ff; July 1978, p. 10;

Ixxxv Drum, 22 November 1973, p. $45 \mathrm{ff}$.

Ixxxvi The Masterpiece in Bronze column did not appear in every edition of Drum. Some of those featured over the course of the 1970s were Doctor Lazarus, September 1976, Hassan Howa, December 1976; Peter Magubane, March 1977; William Ngkane, May 1977; Babsy Mlangeni, July 1977; John Kani, August 1977; Gordon Nongxa, March 1978; Mathews Batswadi, May 1978; Father Ndwandwe, June 1978; Daniel Mapanya, Sept 1978; Peter Lamb, October 1978 and Lucy Mvubelo, November 1978; Don Mateman, February 1979; Beyers Naude, March 1979; Themba Msimang, April 1979; George Pemba, July 1979; Fatima Dike, October 1979; Willie Baqwa, November 1979

Ixxxvii Drum, September 1970, p. 6

Ixxxviii Drum, 8 November 1973, p. 30

Ixxxix Drum, 22 November 1973, p. 31.

xc Drum, December 1957, p. 63; March 1962, p. 20 ff; August 1957, p. 51 ff; September 1957, p. 48.

xci Drum, July 1978, p. 43

xcii See for example 'Matswile: the HNP politician who liked black girls' in Drum, January 1980, p. $20 \mathrm{ff}$

xciii Drum, 8 January 1975, p. 6 ff. The men died after being charged under the Immorality Act allegedly either through stress related illness or through suicide.

xciv A. Ferber, White man falling, p. 21.

xcv T. Barnes, 'We women', p. xxi.

xcvi Mail \& Guardian, April 20-27, 2000, p. 6.

xcvii Mda in G. Gerhardt, Black Power in South Africa: The Evolution of an ideology (Berkeley: University of California Press 1978), p.129. 